\title{
Tree species composition affects productivity and carbon dynamics of different site types in boreal forests
}

\author{
Vladimir Shanin · Alexander Komarov • \\ Raisa Mäkipää
}

Received: 27 March 2013/Revised: 30 August 2013/Accepted: 22 November 2013/Published online: 3 December 2013

(C) Springer-Verlag Berlin Heidelberg 2013

\begin{abstract}
The objective was to analyse how differences in the initial proportions of tree species and site fertility affect carbon sequestration in living biomass and soil. We used the individual-based simulation model EFIMOD, which is able to simulate spatially explicit competition between trees for light and nutrients. Simulations were carried out for three site types with distinct initial stocks of soil nutrients. For each site, the 100-years undisturbed dynamics of monocultures and mixtures of three tree species (Betula pendula Roth, Pinus sylvestris L. and Picea abies (L.) H. Karst.) was predicted. Changes in the proportions of competing tree species were dependent on the fertility of the site: on poor sites, pine was the most competent species, while on rich sites, spruce increased its proportion during stand succession. Net primary production (NPP) and soil respiration were the highest in stands of two coniferous species and in stands with a high initial proportion of pine. Mixed stands were more productive than monocultures; the highest overyielding was observed with mixtures of two coniferous species. Simulated NPP and carbon stocks in all pools increased from poor to rich
\end{abstract}

Communicated by Christian Ammer.

Electronic supplementary material The online version of this article (doi:10.1007/s10342-013-0759-1) contains supplementary material, which is available to authorized users.

V. Shanin $(\bowtie) \cdot$ A. Komarov

Institute of Physicochemical and Biological Problems in Soil

Science, Russian Academy of Sciences, 142290 Institutskaya ul.,

2, Pushchino, Moscow Region, Russian Federation

e-mail: shaninvn@gmail.com

R. Mäkipää

Finnish Forest Research Institute, Jokiniemenkuja 1,

P.O. Box 18, 01301 Vantaa, Finland sites. The highest carbon stocks in standing biomass were observed for mixtures of conifer species and three-species mixtures; the greatest accumulation of forest floor occurred in stands with high proportions of pine.

Keywords Competition - Site fertility - Mixed forest $\cdot$ Scots pine $\cdot$ Norway spruce $\cdot$ Silver birch

\section{Introduction}

In natural ecosystems, plant species grow in mixtures of interacting species and net biomass production is affected by species composition (e.g. Pretzsch 2010; Pretzsch and Schütze 2009). In general, ecological theory predicts that a mixture of coexisting species, which have complementary niches, leads to a greater total use of resources and greater biomass production than less diverse communities (Loreau and Hector 2001; Tilman et al. 2001; Leps 2005). The effect of species mixtures is widely studied in temperate forests (e.g. Pretzsch and Schütze 2009; Morin et al. 2011; Forrester et al. 2013), but less comprehensively in boreal forests where management has favoured monocultures. However, Paquette and Messier (2011) suggested that species richness has more significant influence on productivity in stressful and less diversified boreal forests than in temperate biome. In general, tree species richness in boreal forests tends to have positive influence on biomass production (Gamfeldt et al. 2013). This seems to be the case in stands with spruce-birch mixtures (Mielikäinen 1985; Jõgiste 2000), but not necessarily with all other combinations and proportions of boreal tree species. Hynynen et al. (2011) found that the diameter growth of pine was reduced with a birch mixture, but the height growth of birch was enhanced by pine dominance. Lindén and 
Agestam (2003), who studied mixed and monoculture stands of pine and spruce, concluded that little can be gained by mixed stands of two coniferous species. However, other studies have proposed that conifer mixtures may have a volume increment $10-15 \%$ higher than a pure pine or spruce stand (Pukkala et al. 1994). Pine and spruce are known to have differentiated ecological niches: pine with deeper roots is typical for nutrient poor sites, whereas shallow-rooted spruce grows on moist and fertile habitats. Furthermore, they have differences in the light regimes; pine has a shorter crown length and leaf area distributed higher than in spruce (Lagergren and Lindroth 2002; Morén et al. 2000). Thus, when presented in a common site, their complementary niches may increase resource use efficiency (Morin et al. 2011).

Besides species composition, overall productivity and carbon sequestration in a site are affected by climatic factors and by site fertility. The assessment of species composition effect on biomass production is challenging, especially with competing tree species that have long lifespans and, consequently, collecting experimental data on species interactions requires long-term monitoring over several decades (Pretzsch et al. 2013). Attempts have been made to evaluate the competitive effects of different species using methods based on either individual-based modelling with competition indices (Bella 1971; Liu and Ashton 1995; Porte and Bartelink 2002; Zhao et al. 2006; Thorpe et al. 2010 etc.) or direct measurement of intra- and inter-specific competition (Coates et al. 2009). Both approaches evaluated the competitive effects of several tree species and revealed such effects to be unequal and asymmetric, when a large tree influences a small one but not vice versa, at least if the sizes of the trees are very different (see e.g. Weiner 1990; Stoll and Weiner 2000). Current knowledge on the ecology of tree species can provide insights into competitive interactions between species and guidance to ecosystem management (Pretzsch et al. 2008).

In addition to biomass production, tree species composition has influence on soil carbon stock and nutrient availability (e.g. Olsson et al. 2012; Shanin et al. 2013). Thus, it may be possible to manage forest carbon sequestration and mitigate climate change by careful selection of tree species.

Pretzsch et al. (2013) suggested that the relationship between species mixture and biomass productivity depends on site fertility. However, the majority of the studies have been conducted at a single site or on sites that represent the same fertility level. Thus, it remains highly uncertain which tree species combinations are the most productive under different site conditions and what proportions are optimal for carbon sequestration. In our earlier study, we evaluated shifts in the carbon balance in mixed stands due to climate change on only one site type (Shanin et al. 2013). In the present work, we will make the comparative analyses of successive changes in species composition and the corresponding dynamics of carbon and nitrogen pools on different site types.

The objective of this study was to analyse the biomass production and carbon sequestration capacity of mixed stands with different fertility levels (rich, mesic and poor) with varied tree species composition. We analysed the dynamics of tree species proportions and resulting biomass production with varied initial proportions of Norway spruce, Scots pine and silver birch.

Our hypotheses were that (1) productivity increases in mixed stands of two and three tree species in comparison with monocultures; (2) the positive effect of species mixture is more remarkable on fertile than on poor sites; and (3) mixtures of light-demanding species (pine or birch) grown together with shade-tolerant spruce may result in greater biomass production than mixtures of pine and birch (species with similar environmental requirements).

These hypotheses can be tested by a simulation study using a model that can account for tree species composition in a stand, competition between trees of different species, and variations in soil fertility reflected by site types.

\section{Materials and methods}

To assess the dynamics of forest ecosystems depending on initial species composition and site type, we analysed several key characteristics obtained from outputs of simulations, which were as follows: changes in species composition, amount of carbon in different pools, amount of nitrogen in forms available for nutrition and overall productivity of mixed forest stands.

To analyse the overyielding of each mixture in comparison with monocultures, we followed formula proposed by (Loreau 1998) and calculated the values of $D_{\max }$ as

$D_{\max }=\frac{O_{\mathrm{NPP}}-\max \left(\mathrm{M}_{\mathrm{NPP}}\right)}{\max \left(M_{\mathrm{NPP}}\right)}$,

where $\max \left(M_{\mathrm{NPP}}\right)$ is the maximal monoculture productivity among all species, and $O_{\mathrm{NPP}}$ is the total observed productivity of the given mixture. Overyielding occurs when $D_{\max }>0$ (Loreau 1998; Loreau and Hector 2001). Since NPP has remarkable fluctuations overtime, the average annual values for the whole period of simulation in fully stocked forest stands were used.

Simulation model EFIMOD: short description

The EFIMOD model (Komarov et al. 2003a), being an individual-based type, simulates the development of tree- 


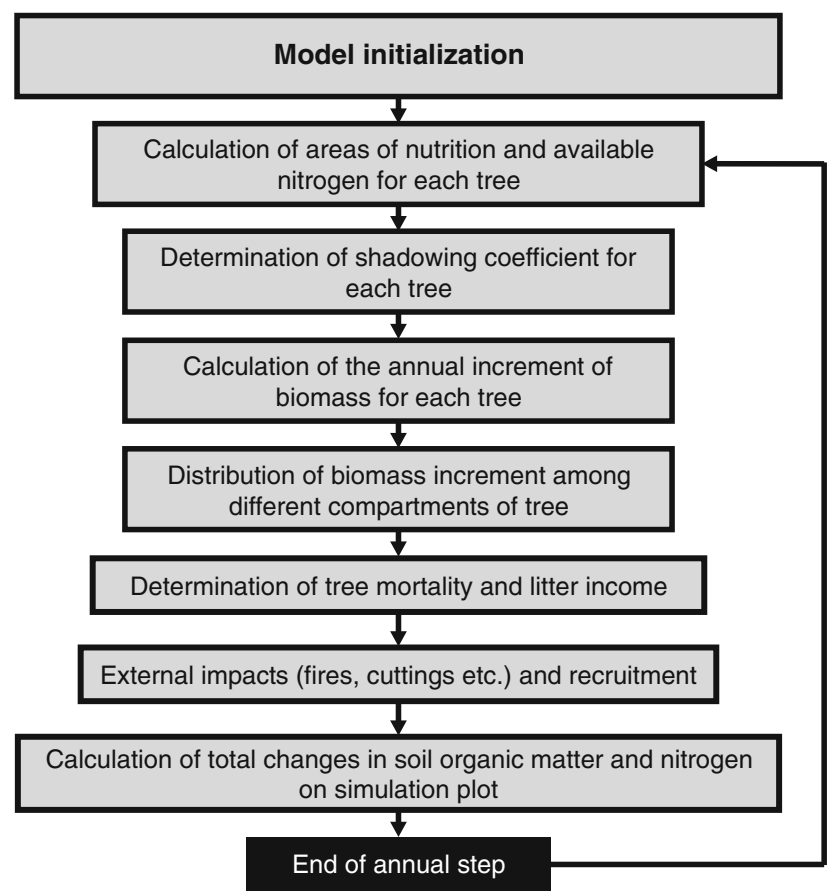

Fig. 1 The flowchart of the annual step of EFIMOD model (from Shanin et al. (2011), as subsequently amended)

soil systems (Fig. 1). The simulated stand consists of separate trees, which are located on a square lattice whose cell is small enough. The annual increment in each tree is distributed among five compartments (stem, branches, leaves/needles, fine roots and coarse roots). The forest growth sub-model is linked with the ROMUL model, which describes dynamics of soil carbon and nitrogen (Chertov et al. 2001) and returns available nitrogen for tree growth. Each tree forms a shadow zone and an area of nutrition whose size depends on the size of tree. Areas of nutrition for neighbouring trees can overlap, and available nitrogen is consumed proportionally to the mass of fine roots of neighbouring trees in these overlapped areas. This definition of belowground competition is species specific and depends on the spreading of roots and their density per square unit, which are different for different species. Thus, two possible types of tree increment can be calculated: that due to light or that due to soil nitrogen (Komarov et al. 2003a). The calculation requires species-specific estimates of leaves/needles and fine roots biomass, maximal biological productivity of leaves/needles and the specific consumption rate of nitrogen. The minimal value of two types of increment is taken as the annual increment, following the Liebig's principle. More detailed description can be found in (Komarov et al. 2003a). Due to the two different types of competition, we inserted simple procedures to simulate adaptations of trees to the lack of the certain resource: (1) if tree increment is restricted by light, then its biomass gain will be allocated mainly to increases in stem height and foliage biomass; (2) conversely, if the growth of a tree is limited by uptake of nitrogen, then the relative increase in biomass of fine roots and stem diameters will be higher than those of foliage and stem height. A deterministic procedure of tree's death is based on the idea of lethal threshold, defined by the ratio of leaf mass $B_{l}$ to total biomass $B_{T}$, below which the tree dies (Eq. 2):

$r=g_{1}-g_{2} \ln B_{T}$,

where $r$ is the lethal ratio $B_{l} / B_{T}$, and $g_{1}$ and $g_{2}$ are speciesspecific parameters evaluated from corresponding regional growth tables. In addition, we inserted a probabilistic mortality function dependent on tree age, which reaches 1.0 at a species-specific maximal tree age.

Our individual-based model indicated type of competition for each tree and shows that starting from approximately 20-30 years old growth of trees is mostly limited by nitrogen. It is in a good correspondence with assumption that for boreal forests, which are usually nitrogen limited (Tamm 1991; Vitousek and Howarth 1991; LeBauer and Treseder 2008; Bobbink et al. 2010; Butterbach-Bahl et al. 2011), the competition for nitrogen in the stand is important and it is stronger than competition for light.

ROMUL is a model describing the dynamics of three main pools of SOM and the corresponding pools of nitrogen: SOM of the forest floor, labile humus of mineral horizons (originating in ROMUL from decomposing root litter) and stable humus of mineral soil consisting of SOM, which originates from humified intermediate products of root litter decomposition and similar humified products that originate from decomposed and transported compounds of forest floor into the mineral layer. They are bonded with soil minerals and have a slow rate of decomposition (Chertov and Komarov 1997). The rates of decomposition are depended on temperature and moisture of forest floor and mineral soil, as well as on the nitrogen and ash content in litter. Additionally, ROMUL calculates a pool of mineral nitrogen available for plant nutrition.

The species composition of the mixed forest stand in the model consists of so-called 'forest elements'. Forest element is an even-aged group of trees of the same species with similar average stem height and diameter with corresponding standard deviations. It should be noted that in spatial individual-based models, each tree which belongs to the same forest element is settled randomly and independently onto empty grid cells. So it could have neighbours from other forest elements. It is main distinction of the spatial individual-based models from gap models where non-spatial cohort of similar trees is studied on average (Bugmann 2001).

We introduced the following volume equation to the model to calculate the growing stock from stem height and diameter (Laasasenaho 1982): 
Table 1 Parameters values for volume equation for different tree species (Zianis et al. 2005)

\begin{tabular}{llllll}
\hline Species & $a$ & $b$ & $c$ & $d$ & $e$ \\
\hline Birch & 0.011197 & 2.10253 & 0.986 & 3.98519 & -2.65900 \\
Spruce & 0.022927 & 1.91505 & 0.99146 & 2.82541 & -1.53547 \\
Pine & 0.036089 & 2.01395 & 0.99676 & 2.07025 & -1.07209 \\
\hline
\end{tabular}

Table 2 Initial soil parameters $\left(\mathrm{kg} \mathrm{m}^{-2}\right)$ for sites representing different fertility levels (poor, medium and rich) used to run soil submodel

\begin{tabular}{llll}
\hline & \multicolumn{2}{l}{ Site fertility } \\
\cline { 2 - 4 } & Poor & Medium & Rich \\
\hline Total SOM $\left(\mathrm{kg} \mathrm{m}^{-2}\right)$ & & & \\
$\quad$ Forest floor & 2.5 & 2.9 & 3.0 \\
Labile humus & 1.3 & 1.5 & 1.7 \\
$\quad$ Stable humus & 8.9 & 9.3 & 10.8 \\
Amount of soil nitrogen $\left(\mathrm{kg} \mathrm{m}^{-2}\right)$ & & & \\
Forest floor & 0.043 & 0.052 & 0.064 \\
Labile humus & 0.018 & 0.027 & 0.042 \\
Stable humus & 0.18 & 0.25 & 0.39 \\
\hline
\end{tabular}

$V=a \cdot D^{b} \cdot c^{D} \cdot H^{d} \cdot(H-1.3)^{e}$,

where $V$ is the stemwood volume, $D$ is stem diameter, $H$ is height and $a-e$ are the parameter values (Table 1), as reported in (Zianis et al. 2005).

Parameterization of the model

\section{Soil data}

Our simulations were focused on three different fertility levels, i.e. poor, medium and rich sites. The characteristics of the simulated sites correspond to the most common site types in southern and central Finland, i.e. Vaccinium type (VT), Myrtillus type (MT) and Oxalis-Myrtillus type (OMT) forests, according to fertility classes applied in Finland (Cajander 1926, 1949; Hotanen et al. 2008). On the most fertile site (OMT), understory vegetation includes several herb and grass species together with dwarf shrubs. The site name comes from Oxalis acetosella (L.) and Vaccinium myrtillus (L.), which both are frequent and abundant on this site type. On MT, which is named according to $V$. myrtillus, herbs are less frequent, and on VT [named according to Vaccinium vitis-idaea (L.)], very few herb species are observed.

We used values reported in Tamminen (1991) as initial values for carbon and nitrogen pools in the forest floor and in the mineral soil (Table 2). Organic matter in mineral soil is described as the sum of stable humus and labile humus
Table 3 Physical properties of forest floor and mineral soil

\begin{tabular}{lll}
\hline Physical properties & Forest floor & Mineral soil \\
\hline Bulk density, $\mathrm{g} \mathrm{cm}^{-3}$ & 0.14 & 1.35 \\
$\begin{array}{l}\text { Moisture at permanent wilting } \\
\text { point, vol. \% }\end{array}$ & 7.1 & 7.1 \\
$\begin{array}{l}\text { Moisture at field capacity, vol. \% } \\
\begin{array}{l}\text { Total porosity (or moisture at } \\
\text { full saturation), vol. \% }\end{array}\end{array}$ & 33.0 & 29.0 \\
\hline
\end{tabular}

originating from root litter. The initial amount of labile humus was assumed to be $15 \%$ of total organic matter measured for mineral soil, and the corresponding nitrogen pool was assigned on the assumption that the $\mathrm{C} / \mathrm{N}$ ratio of labile humus is similar to the $\mathrm{C} / \mathrm{N}$ ratio of the forest floor.

Soil variability was taken into account by calculating Monte Carlo runs with a $20 \%$ standard deviation from the average.

\section{Climate scenarios}

Climatic data were based on the 47-year (1961-2007) period measured from meteorological stations interpolated onto a $10 \times 10 \mathrm{~km}$ grid by the Finnish Meteorological Institute (Venäläinen et al. 2005). In this study, we used data from the grid cell closest to the Hyytiälä/Smear II station. The 47-year data series was detrended and repeated to obtain climate data for the whole 100-year simulation period in the ambient climate model.

Soil temperature as well as moisture was estimated using the SCLISS model (Bykhovets and Komarov 2002; Komarov et al. 2007). Soil physical properties required for soil moisture simulation (Table 3) were based mainly on data from the Hyytiälä Experimental Catchments (Ilvesniemi et al. 2010) and did not differ according to site type.

\section{Species-specific data}

Allocations of annual tree increments to different tree compartments: stem, foliage, branches, coarse and fine roots in relation to the age status of the tree were the main model calibration parameters, similar to Komarov et al. (2003a). These periods are based on the concept of discrete description of plants ontogeny, which is well known in plant population ecology (Gatzuk et al. 1980; Smirnova et al. 1999; Smirnova and Bobrovskii 2001; Komarov et al. 2003b). In the context of the model discussed and in relation to stand development, it is more close to stages by Oliver and Larson (1996), e.g. young and strong selfthinning phase, mature stable phase and old-growth phase. Age status is represented by three ontogenetic periods: young, mature and over-mature trees. Each group of trees 
in current ontogenetic stage has certain species-specific coefficients of allocation of annual tree increments. Allocation coefficients are also site-type specific and were calibrated in correspondence with growth tables for pure stands (Shvidenko et al. 2006). These coefficients play a crucial role in the competitive abilities of tree species (Komarov et al. 2003a). They define characteristics of trees, which are important for simulation of both aboveand belowground competition, i.e. crown and root system development. The success in competition for light is depended on aboveground biomass and, therefore, tree's height and crown size, and success in competition for available nitrogen is depended on the biomass of fine roots. For the description of mixed forests, we used the model calibration for pure stands (Shvidenko et al. 2006). Such a calibration may have shortcomings (Pretzsch and Schütze 2009), but adaptations of individual trees to deficits of light or nitrogen and species-specific tree characteristics and responses to competition will compensate the specific dynamics of mixed stands.

Verification of the model and analysis of uncertainties

We performed Monte Carlo runs of the model using the initial soil data distributed with a $20 \%$ standard deviation from the average. These simulations provided predicted dynamics for some key characteristics (average height and diameter, stand density and basal area) of pure stands for all three species. We compared simulated data versus observed [yield tables and data reported by Ilvessalo and Ilvessalo (1975)], as proposed in Piñeiro et al. 2008. The comparison showed strong correlation with $R^{2}=0.97$ and slope value of 0.994 for the number of trees, and $R^{2}=0.98$ and slope value of 1.008 for the average stem height $(p<0.001)$.

The model has some limitations related to the simple sub-model of productivity, which, on the other hand, requires a small number of parameters for initialization. As a consequence, EFIMOD is not able to simulate, for example, the negative effect of drought stress on productivity (Martínez-Vilalta et al. 2008; Huang et al. 2010; Hartmann 2011; Bauwe et al. 2012). We believe that introducing a more detailed ecophysiological model to our simulation experiments will deliver more clarity to this issue. Another necessary improvement is a more detailed model of belowground competition taking into account the effects of 'niche segregation' in mixed stands (Sterba et al. 2002; Rewald and Leuschner 2009; Cavard et al. 2011).

Simulation of soil organic matter dynamics could be improved by including more detailed models, for example by accounting for soil biota dynamics (Kuzyakov et al. 2000; Talbot et al. 2008). However, it is of great importance to maintain a balance between a sufficiently detailed model and the number of parameters, which are required for its initialization. In the context of experimental accuracy, complication of the model structure can lead to uncertainties originating from the joint action of uncertainties for individual parameters (Larocque et al. 2008).

Sensitivity analyses for EFIMOD showed that the tree sub-model is highly sensitive to changes in the reallocation of the biomass increment and tree mortality functions, while the soil sub-model is sensitive to the proportion and mineralization rate of stable humus in the mineral soil. Overall, the model is very sensitive to all nitrogen compartments, including $\mathrm{N}$ required for tree growth, $\mathrm{N}$ withdrawal from senescent needles, soil $\mathrm{N}$ and $\mathrm{N}$ deposition from the atmosphere (Komarov et al. 2003a).

Initial parameters and scenarios of simulation

Initial datasets with different species composition and their initial shares were constructed for the simulations. They consisted of two-species mixtures (birch and pine, birch and spruce, pine and spruce) with different initial proportions $(9: 1,7: 3,5: 5,3: 7,1: 9)$. These shares represented different kinds of mixed forests: 'almost pure' stands with a small admixture of another species, equal share and an intermediate case. Additionally, initial sets representing mixed stands with all three species in various proportions $(2.5: 2.5: 5,2.5: 5: 2.5$ or $5: 2.5: 2.5)$ were constructed. Total initial stand density in all cases was set to 10,000 trees $\mathrm{ha}^{-1}$. Short codes for initial species composition are used for their representation on figures. Such codes consist of the first letter of the names of the species in the mixture and their proportional factors. For example, code 7P3S denotes a stand with initial proportions of pine and spruce equal to 70 and $30 \%$, respectively.

Regeneration was simulated as the planting of new trees every 10 years with a total density of 2,000 trees ha ${ }^{-1}$. Shares of species were the same as existed on the site at the moment of regeneration (the basal area was taken as the basis for calculation of the share); the quantity of birch saplings was taken to be two times higher than calculated on the basis of existing species proportions because of the higher seed productivity of this species. We used approximate rather than exact estimates of the quantity of seedlings because we applied spatially explicit models of crown and root competition, which simulate self-thinning due to competition and determine the number of trees of each species, 'smoothing out' errors in determining their initial amounts. Initial displacement of saplings was described by contagious distribution (Grabarnik and Särkka 2009). The age of all saplings at regeneration was 5 years; the values for stem height and diameter (Electronic supplementary material 1, Table A1) were taken from the corresponding yield tables (Shvidenko et al. 2006). 
Table 4 Changes in portions of species by the end of simulation period (final-to-initial species portion ratio) on poor, medium and rich sites $\pm \mathrm{SD}$ obtained from Monte Carlo runs

\begin{tabular}{|c|c|c|c|}
\hline & \multicolumn{3}{|l|}{ Site fertility } \\
\hline & Poor & Medium & Rich \\
\hline \multicolumn{4}{|l|}{ Pine portion } \\
\hline $90 \%$ Birch $10 \%$ Pine & $3.269 \pm 1.173$ & $0.109 \pm 0.033$ & $0.134 \pm 0.032$ \\
\hline $70 \%$ Birch $30 \%$ Pine & $2.019 \pm 0.501$ & $0.421 \pm 0.124$ & $0.14 \pm 0.033$ \\
\hline $50 \%$ Birch $50 \%$ Pine & $1.577 \pm 0.532$ & $0.494 \pm 0.146$ & $0.238 \pm 0.085$ \\
\hline $30 \%$ Birch $70 \%$ Pine & $1.19 \pm 0.416$ & $0.955 \pm 0.277$ & $0.231 \pm 0.069$ \\
\hline $10 \%$ Birch $90 \%$ Pine & $1.027 \pm 0.259$ & $0.996 \pm 0.288$ & $0.444 \pm 0.102$ \\
\hline \multicolumn{4}{|l|}{ Spruce portion } \\
\hline $90 \%$ Birch $10 \%$ Spruce & $3.299 \pm 0.806$ & $18.912 \pm 5.788$ & $21.197 \pm 5.295$ \\
\hline $70 \%$ Birch $30 \%$ Spruce & $1.822 \pm 0.482$ & $5.911 \pm 1.749$ & $5.824 \pm 1.823$ \\
\hline $50 \%$ Birch $50 \%$ Spruce & $1.383 \pm 0.446$ & $3.091 \pm 0.966$ & $3.075 \pm 1.03$ \\
\hline $30 \%$ Birch $70 \%$ Spruce & $1.06 \pm 0.271$ & $1.906 \pm 0.553$ & $1.921 \pm 0.638$ \\
\hline $10 \%$ Birch $90 \%$ Spruce & $0.905 \pm 0.253$ & $1.239 \pm 0.356$ & $1.236 \pm 0.307$ \\
\hline \multicolumn{4}{|l|}{ Spruce portion } \\
\hline $90 \%$ Pine $10 \%$ Spruce & $0.766 \pm 0.269$ & $1.373 \pm 0.427$ & $5.14 \pm 1.72$ \\
\hline $70 \%$ Pine $30 \%$ Spruce & $1.166 \pm 0.377$ & $1.704 \pm 0.526$ & $6.825 \pm 2.61$ \\
\hline $50 \%$ Pine $50 \%$ Spruce & $0.729 \pm 0.198$ & $2.345 \pm 0.676$ & $5.068 \pm 1.273$ \\
\hline $30 \%$ Pine $70 \%$ Spruce & $0.862 \pm 0.222$ & $2.3 \pm 0.657$ & $3.115 \pm 0.883$ \\
\hline $10 \%$ Pine $90 \%$ Spruce & $0.974 \pm 0.306$ & $1.371 \pm 0.392$ & $1.57 \pm 0.46$ \\
\hline \multicolumn{4}{|l|}{ Pine portion } \\
\hline $20 \%$ Birch $20 \%$ Pine $40 \%$ Spruce & $1.208 \pm 0.386$ & $3.544 \pm 1.023$ & $4.287 \pm 1.156$ \\
\hline $20 \%$ Birch $40 \%$ Pine $20 \%$ Spruce & $0.16 \pm 0.041$ & $3.431 \pm 0.999$ & $10.46 \pm 2.89$ \\
\hline $40 \%$ Birch $20 \%$ Pine $20 \%$ Spruce & $0.926 \pm 0.215$ & $5.85 \pm 1.721$ & $10.553 \pm 3.036$ \\
\hline \multicolumn{4}{|l|}{ Spruce portion } \\
\hline $25 \%$ Birch $25 \%$ Pine $50 \%$ Spruce & $1.676 \pm 0.577$ & $0.101 \pm 0.031$ & $0.125 \pm 0.034$ \\
\hline $25 \%$ Birch $50 \%$ Pine $25 \%$ Spruce & $1.633 \pm 0.598$ & $0.923 \pm 0.28$ & $0.312 \pm 0.098$ \\
\hline $50 \%$ Birch $25 \%$ Pine $25 \%$ Spruce & $2.662 \pm 0.868$ & $0.467 \pm 0.145$ & $0.103 \pm 0.035$ \\
\hline
\end{tabular}

The scenarios of simulation assumed no management. In order to analyse the uncertainties, we ran the model in Monte Carlo mode with initial data on stands and soil distributed with a $20 \%$ standard deviation. The model outputs were the average values and standard deviations.

\section{Results}

Changes in species composition

Our results showed major changes in tree species composition during stand succession. The performance of different tree species was dependent on the initial proportions of tree species as well as on site fertility.

In mixed birch-pine stands, pine increased its proportion on sites that were poor in terms of soil nutrition. The most remarkable increase (more than threefold) was observed in stands with the lowest initial proportion of pine (10\%). On more fertile sites, there was a decrease in the proportion of pine, the most remarkable in the case with $10 \%$ pine initially. In general, the decrease in pine proportion was the highest on the most fertile site (Table 4).

In mixed birch-spruce stands, spruce overcompeted birch in all sites and under all initial proportions. The increase in the proportion of spruce among different initial compositions was the greatest in stands initially dominated by birch. Among different site types, the greatest increase in proportion of spruce was observed on the most fertile site and the lowest on the poor type (Table 4).

In mixed pine-spruce stands, pine generally increased its proportion on poor sites and spruce increased its proportion on more fertile sites. The relative increase in the spruce proportion was higher on rich, compared to medium, sites. In both the above cases, the relative increase in the proportion of spruce was higher than the relative increase in the proportion of pine on poor sites (Table 4).

In mixed stands with all three tree species, pine was the most competitive species and increased its proportion on poor sites, whereas the proportion of spruce did not change or decrease. In contrast, on more fertile sites, the proportion of pine decreased and the proportion of spruce 
Fig. 2 Net primary production (NPP), heterotrophic respiration (in terms of carbon) and carbon balance (NPP minus $\mathrm{CO}_{2}$ emission) at different initial proportions of species on rich site. Average values over the whole period of simulation and standard deviations obtained from Monte Carlo runs. Labels on $X$-axis denote initial species composition where letters are the first letters of species' names and numbers are theirs proportional factors

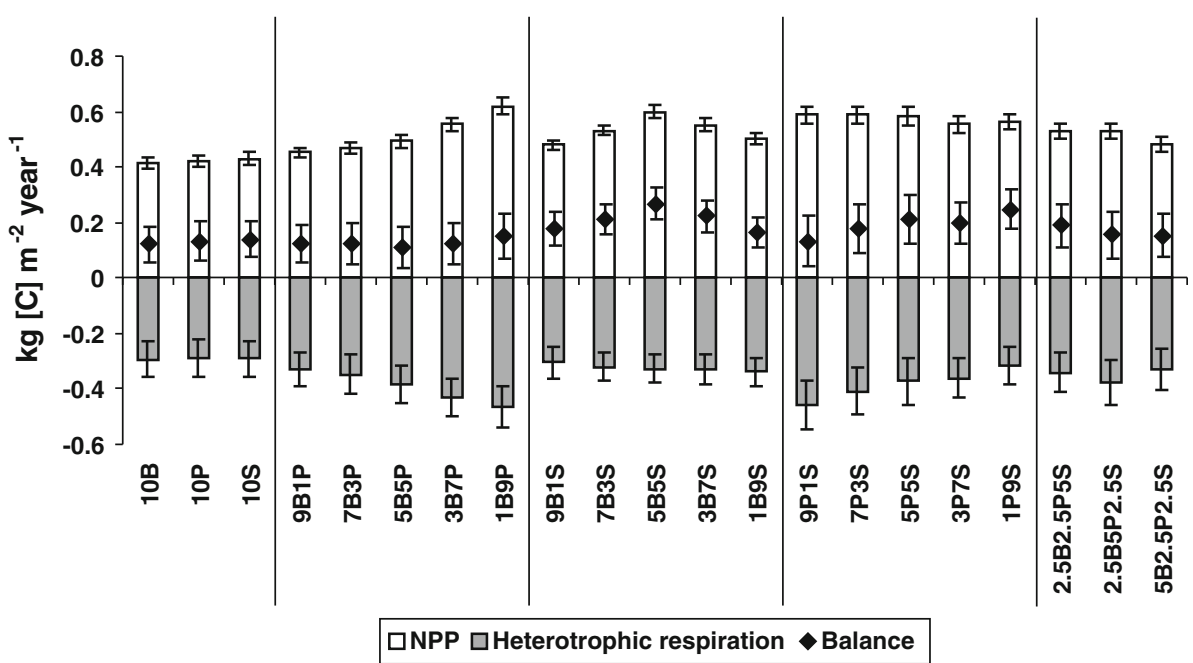

increased. This trend was generally more remarkable on the richest sites (Table 4). Birch was almost completely eliminated by the end of simulation period.

More detailed dynamics of species composition can be found in Electronic supplementary material 1, Figures A1A4.

\section{Carbon balance}

Net primary production (NPP) and heterotrophic respiration $\left(R_{\mathrm{h}}\right)$ increased from poor to rich sites. In comparison with the least fertile site, NPP was $\sim 20 \%$ higher for intermediate and $\sim 30 \%$ higher for the richest sites, and the corresponding increases in $R_{\mathrm{h}}$ were $\sim 12$ and $\sim 22 \%$. In all cases, the net ecosystem productivity (NEP) was positive.

On poor sites, the NPP by monocultures was the highest in pine stands (as was also the case with $R_{\mathrm{h}}$ ) and on more fertile sites in spruce stands (in these cases, differences in $R_{\mathrm{h}}$ values were insignificant). In birch-pine stands, both $R_{\mathrm{h}}$ and NPP increased with increasing proportions of pine; this increase was the most remarkable on the richest site. The values of NPP were $0.32-0.46 \mathrm{~kg}[\mathrm{C}] \mathrm{m}^{-2}$ year $^{-1}$, and the values of $R_{\mathrm{h}}$ were $0.28-0.33 \mathrm{~kg}[\mathrm{C}] \mathrm{m}^{-2}$ year $^{-1}$ for poor sites. In birch-spruce stands, NPP was the highest ( $\sim 0.37 \mathrm{~kg}[\mathrm{C}] \mathrm{m}^{-2}$ year $^{-1}$ on the poor site) in the case of equal initial proportions of birch and spruce. The values of $R_{\mathrm{h}}$ were around $\sim 0.22 \mathrm{~kg}[\mathrm{C}] \mathrm{m}^{-2}$ year $^{-1}$ for the poor site, without any clear trend. In mixed pine-spruce stands, both $R_{\mathrm{h}}$ and NPP decreased with increasing proportions of spruce, but for the latter this increase was unremarkable. Values of NPP were around $\sim 0.48 \mathrm{~kg}[\mathrm{C}] \mathrm{m}^{-2}$ year $^{-1}$, and values of $R_{\mathrm{h}}$ were $0.28-0.38 \mathrm{~kg}[\mathrm{C}] \mathrm{m}^{-2}$ year $^{-1}$ for poor sites. Among three-species stands, higher values of NPP $\left(\sim 0.50 \mathrm{~kg}[C] \mathrm{m}^{-2}\right.$ year $^{-1}$ for poor sites $)$ were observed in stands with initial domination by pine and spruce, while the highest $R_{\mathrm{h}}\left(\sim 0.33 \mathrm{~kg}[\mathrm{C}] \mathrm{m}^{-2}\right.$ year $^{-1}$ on the poor site) was observed in initially pine-dominated stands. As all the trends listed above were similar for all site types, bar plot is shown only for rich site (Fig. 2) where differences between tree species combinations are the most remarkable.

The effect of species mixtures on NPP was clearly positive in mixtures of coniferous species and also in some of the birch mixtures (Fig. 3, see also Electronic supplementary material 1, Figures A5-A6). The effect was the most remarkable on the most fertile sites. In mixed stands of birch and pine, the values of $D_{\max }$ increased with increasing initial portion of pine. Its value was especially positive in cases initially dominated by pine. In mixed birch-spruce stands, $D_{\max }$ was the highest in the case with equal initial proportions of both species, and this was the only case where $D_{\max }$ was considerably higher than 0 for all site types. In mixed pine-spruce stands with all initial proportions of these tree species, the $D_{\max }$ value was remarkably higher than 0 . In mixed stands of all three species, $D_{\max }$ was also $>0$, being the highest in the case of initial domination by conifers. In general, in most of the mixtures, there was an increase in values of $D_{\max }$ from the poor to the rich site. This characteristic was the highest in stands initially dominated by pine.

\section{Available nitrogen}

In mixed birch-pine stands, the amount of mineral $\left(\mathrm{NH}_{4}{ }^{+}\right.$ and $\mathrm{NO}_{3}{ }^{-}$) nitrogen in soil increased with increasing proportions of pine on poor site. On more fertile sites, it was similar for all initial proportions, except it had relatively lower values for the case of $90 \%$ pine initially. In mixed birch-spruce stands, the amount of available nitrogen increased with increasing proportion of spruce. In mixed pine-spruce stands, the amounts of available nitrogen were 
Fig. 3 The measure of overyielding $\left(D_{\max }\right.$, see explanations in the text) calculated for the whole period of simulations. Overyielding occurs when $D_{\max }>0$. Average values over the whole period of simulation and standard deviations obtained from Monte Carlo runs. Labels on $X$-axis denote initial species composition where letters are the first letters of species' names and numbers are theirs proportional factors
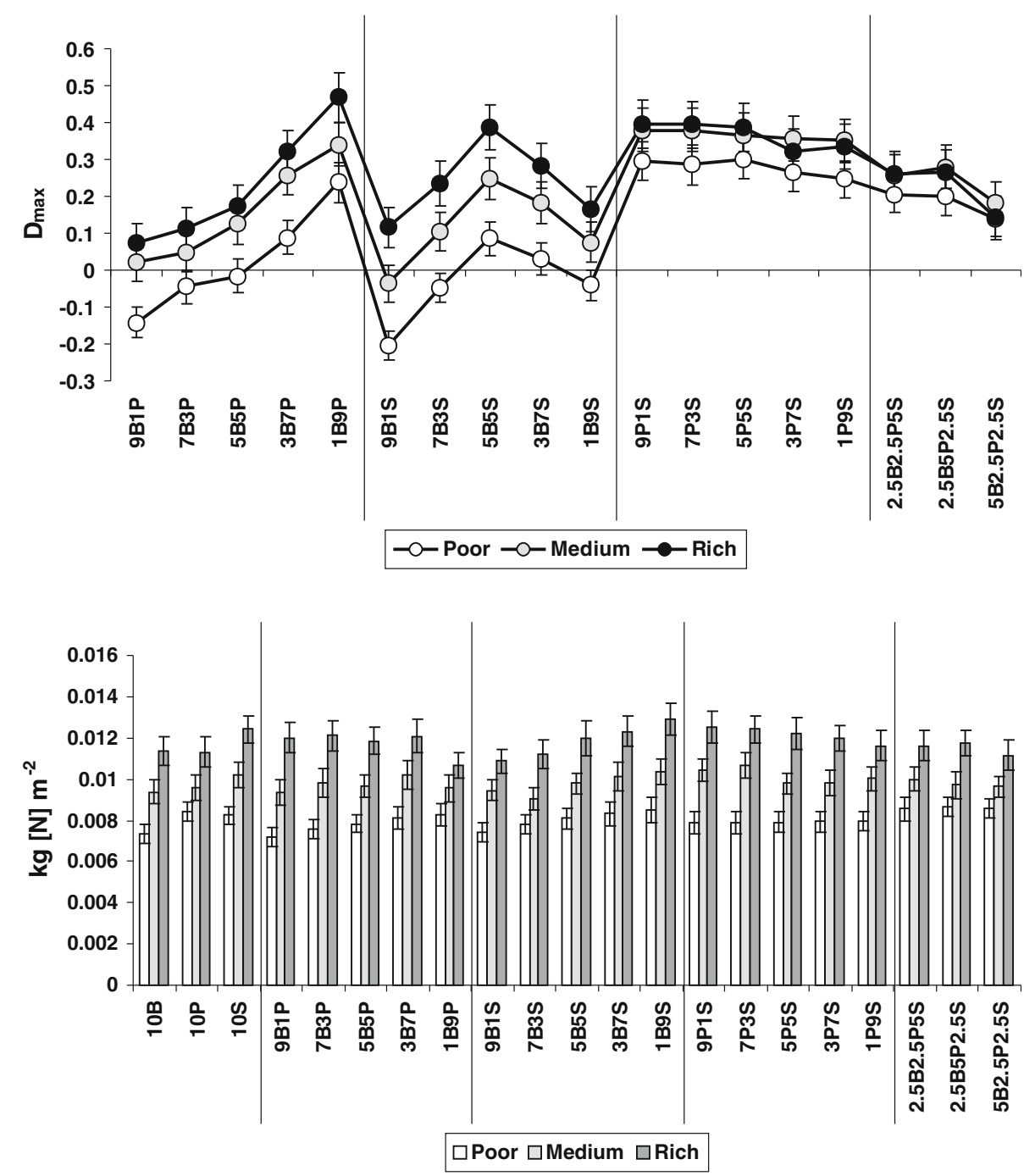

Fig. 4 Average values and standard deviations obtained from Monte Carlo runs for available nitrogen over the whole period of simulation. Labels on $X$-axis denote initial species composition where letters are the first letters of species' names and numbers are theirs proportional factors similar for any initial species proportions on richer sites and decreased with increasing initial proportion of spruce on the richest site. Three-species mixtures showed no remarkable differences in the average amount of available nitrogen in soil. Among pure stands, the amount of available nitrogen was the highest in pine stands on poor site and in spruce stands on other sites.

The variation in nitrogen between site types $(\sim 20 \%)$ was much larger than that introduced by varied initial species composition (generally no more than $8 \%$ ). The average values for the amount of available nitrogen were $0.0081 \mathrm{~kg} \mathrm{~m}^{-2}$ year $^{-1}$ for poor, 0.0098 for medium, and $0.0118 \mathrm{~kg}[\mathrm{~N}] \mathrm{m}^{-2}$ for rich sites (Fig. 4).

The dynamics of basic carbon pools

\section{Standing biomass}

The general trend, independent from initial species composition, showed an increase in average carbon stock in standing biomass from poor to rich sites. The average carbon stock of standing biomass on medium sites was 10-20\% higher and on rich sites 20-30\% higher, than on poor sites (Fig. 5).

The highest carbon stock in standing biomass (9-14 $\mathrm{kg}[\mathrm{C}] \mathrm{m}^{-2}$ for the poor site) was observed in mixed pine-spruce stands with high initial proportions of pine and in three-species mixtures. In mixed birch-pine stands, the highest carbon stock was observed in the case of equal initial proportions of both species. The annual average carbon stock for poor site was 5-6 $\mathrm{kg}[\mathrm{C}] \mathrm{m}^{-2}$. Mixed stands of pine and birch also showed the highest relative increases in carbon stock on rich sites in comparison with other sites. In mixed birch-spruce stands, the corresponding carbon stock increased with increasing initial proportions of spruce; the average value for poor site was $4-5 \mathrm{~kg}[\mathrm{C}] \mathrm{m}^{-2}$. Among mixed pine-spruce stands, those with high initial proportions of spruce showed remarkably higher carbon stock in standing biomass in comparison with initially birch-dominated stands (11-14 vs. $7-8 \mathrm{~kg}[C] \mathrm{m}^{-2}$ for poor site). Pure stands, in 
Fig. 5 Average values and standard deviations obtained from Monte Carlo runs for carbon stocks in standing biomass over the whole period of simulation. Labels on $X$-axis denote initial species composition where letters are the first letters of species' names and numbers are theirs proportional factors
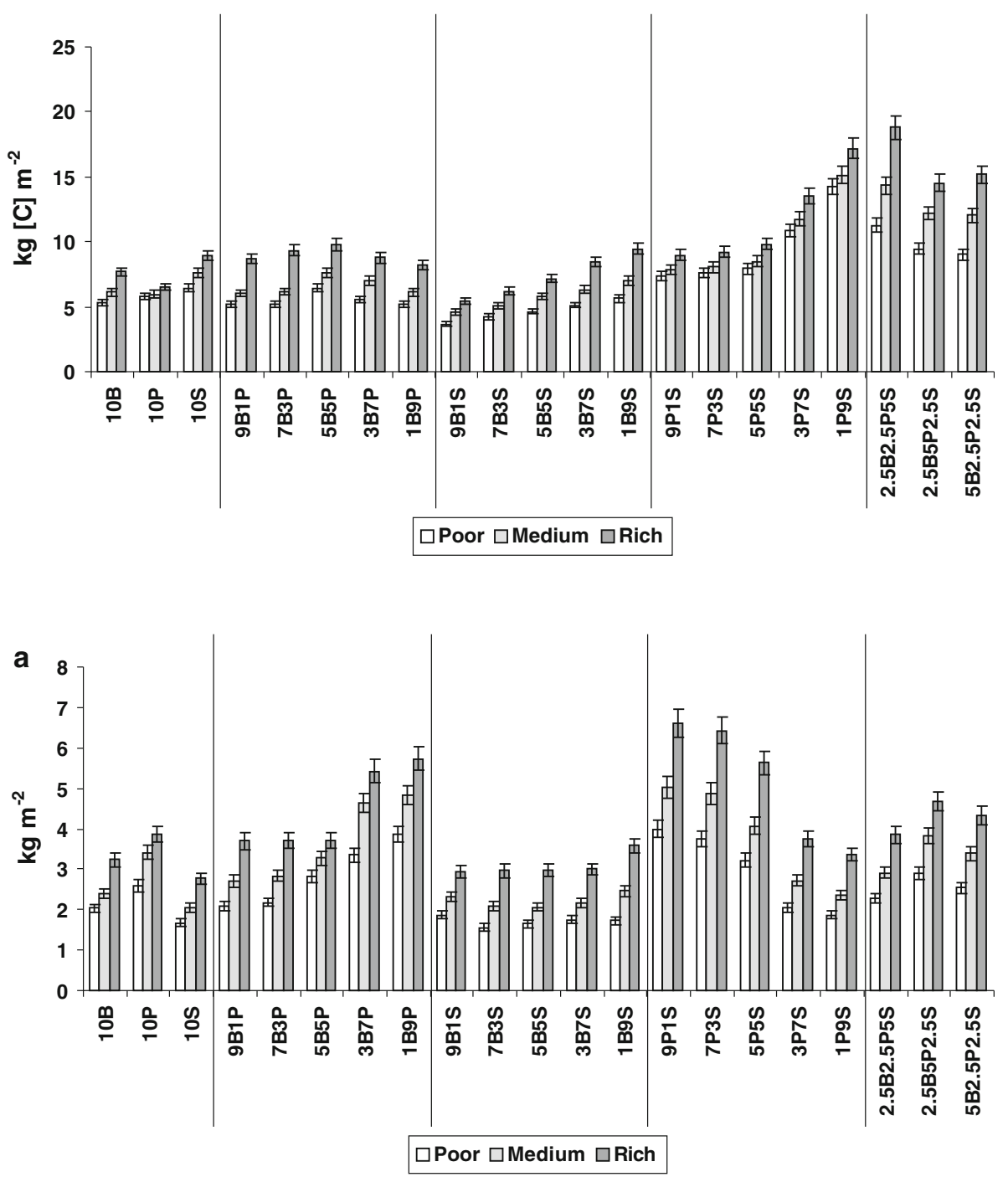

Fig. 6 Average values and standard deviations obtained from Monte Carlo runs for forest floor (a) and mineral soil (b) over the whole period of simulation. Labels on $X$-axis denote initial species composition where letters are the first letters of species' names and numbers are theirs proportional factors

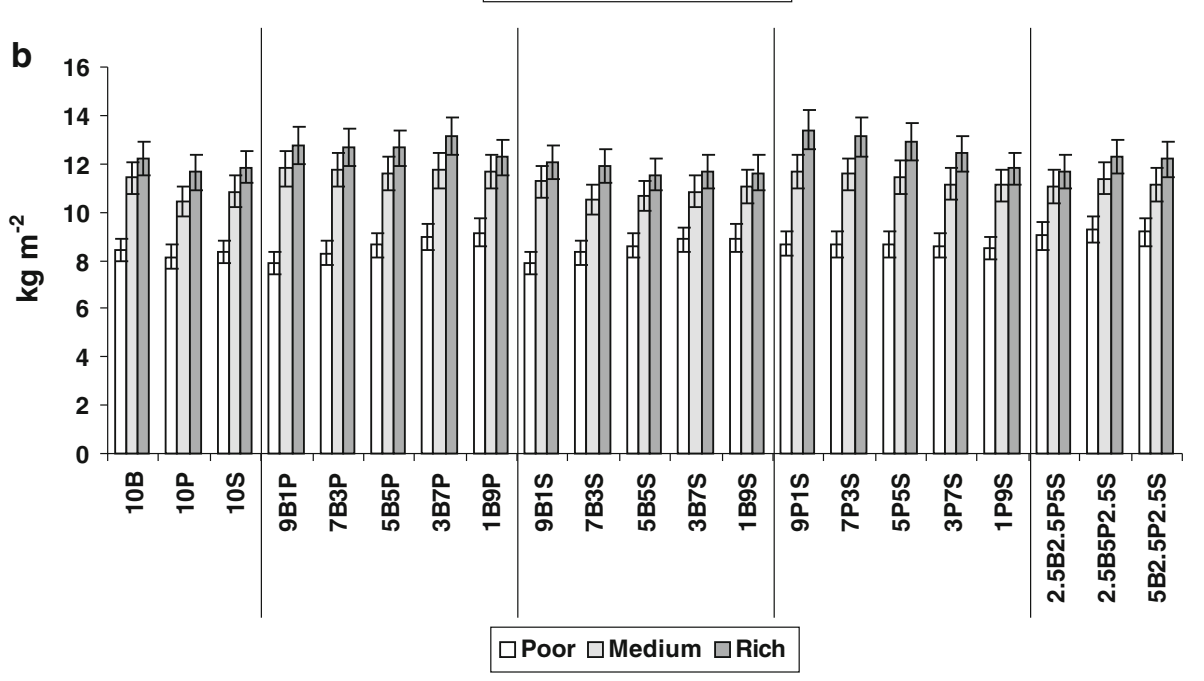

general, showed lower carbon stock in standing biomass than two-species mixtures $\left(5-6 \mathrm{~kg}[\mathrm{C}] \mathrm{m}^{-2}\right.$ ), and in three-species stand, this parameter was higher $\left(9-11 \mathrm{~kg}^{2}[\mathrm{C}] \mathrm{m}^{-2}\right.$ ) than the average for two-species stands. Among both pure and three-species stands, the highest values of carbon stocks were observed in stands with spruce domination. 


\section{Soil}

Among pure stands, the highest stock of forest floor was observed in pine stands. In contrast, the amount of forest floor in spruce stands was the lowest. In mixed birch-pine stands, the average values of forest floor were remarkably higher in the case of a higher initial proportion of pine (3.3-3.8 vs. $2.1-2.8 \mathrm{~kg} \mathrm{~m}^{-2}$ for poor site) and increased with increasing proportions of pine. In mixed pine-spruce stands, the corresponding carbon stock decreased with increasing initial proportion of spruce from 4 to $1.8 \mathrm{~kg} \mathrm{~m}^{-2}$ for poor sites. In mixed birch-spruce stands, the amount of forest floor was the lowest among all the cases and did not change notably, independent of initial species proportion. The values were $1.5-1.8 \mathrm{~kg} \mathrm{~m}^{-2}$ for poor sites. In three-species mixtures, the highest accumulation of carbon in the forest floor was observed in stands initially dominated by pine (Fig. 6a).

The organic matter in mineral soil generally showed less variation among different initial proportions of species than the forest floor. This parameter varied between 8 and $9 \mathrm{~kg} \mathrm{~m}^{-2}$ for poor sites. Higher values were observed in pine-dominated stands for all site types. As with the previous three pools, the amount of organic matter in mineral soil was the lowest for poor, higher for medium and the highest for rich sites. The difference between medium and rich sites was less than the difference between poor and medium sites (Fig. 6b).

Regardless of the different dynamics of species composition between different site types, the carbon stocks in different pools showed quantitative rather than qualitative differences, depending on site type.

\section{Stemwood production}

The average annual stemwood production had, in general, the same pattern among all cases as the average carbon stock in standing biomass, but with smaller relative differences between variations in initial species composition and between different sites. The highest stemwood production $\left(\sim 12 \mathrm{~m}^{3} \mathrm{ha}^{-1}\right.$ year $^{-1}$ for the poor site) was observed in three-species mixtures. In two-species mixtures, this parameter was usually $8-10 \mathrm{~m}^{3} \mathrm{ha}^{-1} \mathrm{year}^{-1}$ for poor site.

\section{Discussion}

The dynamics of species composition

Our results showed that changes in the proportions of competing tree species were dependent on the fertility of the site. Pine, being a less nutrient-demanding species, had a competitive advantage in poor site, whereas in richer habitats, pine was unable to compete either with spruce or with birch. The shift from pine to other tree species was fastest on the most fertile site. In spruce-birch stands, highly competitive and nutrient-demanding spruce outcompeted birch on sites of rich and intermediate fertility level, but not on poor site. The simulated dynamics of the three tree species is in agreement with earlier studies on mixed stands (Kelty 1992, 2006; Thelin et al. 2002), and our findings regarding the competitive status of the tree species in different phases of stand development are consistent with knowledge of the ecological features of these species (Ilvessalo and Ilvessalo 1975).

\section{Ecosystem productivity}

Our study allows assuming that differences in primary production were more remarkable between site types than those introduced by varied initial tree species composition. Although varied tree species composition affected the carbon stock of the forest floor, which is the most dynamic part of the forest soil, it had relatively little influence on nitrogen availability, which varied strongly according to site type, as has also been shown by empirical study (Smolander and Kitunen 2011). Thus, our results indicate that site productivity is strongly controlled by edaphic factors that are not much changed by tree species composition over a 100 -year period.

We showed that the tree species composition had remarkable influence on productivity. In particular, mixtures of coniferous tree species increased stemwood production in comparison with that in pure pine and spruce stands. Our results are in agreement with earlier growth simulations conducted with a spatial individual-tree growth model that indicated a 10-15\% higher volume increment in a conifer mixture than in pure stands (Pukkala et al. 1994). They concluded that in a mixed spruce-pine stands on medium fertility level, the intra-specific competition of spruce was higher than inter-specific competition (Pukkala et al. 1994), which is prerequisite for positive mixture effect to occur (e.g. Kelty 1992, 2006). Stemwood production was also increased in all different site types with a birch admixture, but the optimal birch proportion was different in spruce and pine stands. In spruce-birch stands, the highest production was obtained with a small proportion of birch, which is consistent with empirical studies by Mielikäinen (1985) and Jõgiste (2000). Similarly, Légaré et al. (2004) showed that deciduous admixture had positive effect on black spruce if the proportion of trembling aspen was lower than $40 \%$. In pine-birch stands, the most favourable proportion was $1: 1$, independent of site fertility. Empirical growth studies by Mielikäinen (1980) showed that in young stands, the most productive were mixed 
stands where pine and birch had equal proportions, but in older stands, the volume growth was slightly negatively affected by increasing proportions of birch.

Our analysis of NPP in monocultures and in mixtures of two or three species demonstrated that overall productivity was increased in mixed stands. This may result from complementary use of resources or from differences in the long-term growth rhythms of different tree species (e.g. Hector 1998; Pretzsch and Schütze 2009; Morin et al. 2011). We analysed the performance of the sites over a relatively long (100 year) period with a succession of competing tree species, which is more likely to show a positive effect of diversity than short-term studies (Cardinale et al. 2007). The performance of the mixed stands in comparison with the maximum NPP of monocultures of all the component species indicated that overyielding was the most remarkable with mixtures of coniferous species. This positive biodiversity effect can be explained by complementarity (niche segregation) and, in the case of pine and spruce, by their differences in light exploitation strategies (Morén et al. 2000). This can lead to more efficient use of resources, as also suggested by Morin et al. (2011). On the other hand, overyielding in stands with birch admixtures was observed on fertile sites, but on poor sites the species mixtures had negative effects on NPP. Species facilitation and overyielding have also been observed to be dependent on site fertility in mixtures of deciduous species in temperate forest, but they found the most significant overyielding on poor sites (Pretzsch et al. 2010, 2013). However, recent conceptual models (Holmgren and Scheffer 2010) and simulations (Morin et al. 2011) as well as experimental studies (Forrester et al. 2013) have shown that positive interactions may actually be more prominent under moderate environmental conditions. In general, we observed the highest overyielding on fertile sites, but our results from relatively harsh boreal conditions cannot be generalized to more productive temperate forests, where positive mixture effect was observed on fertile beech-dominated stands, but not on spruce-dominated stands. On fertile beech sites, the high intra-specific competition is supposed to be reduced by admixture of spruce, which can explain positive mixture effect (Pretzsch et al. 2010).

Our findings indicate that in a mixture of coniferous and deciduous species, competition for nutrients is more pronounced than in mixtures of coniferous species. Particularly on poor site, the realized niches of spruce and birch overlapped, as shown by $D_{\max }$ values that were below 0 (Loreau 1998; Morin et al. 2011). In pine-birch stands, overyielding was observed where the initial proportion of birch was small or where the proportion of birch increased over the simulation period. These are the cases where interspecific competition was the least intensive and where a long study period allowed niche partitioning overtime (Cardinale et al. 2007).

Processes in soil

It is known that the rate of decomposition of plant residues in soil increases, to some extent, with increasing temperature, soil moisture and nitrogen content in the litter (e.g. Davidson and Janssens 2006; Tuomi et al. 2008; Hobbie et al. 2012; Norris et al. 2013). The same was observed in the present study, where carbon dioxide emissions due to heterotrophic respiration increased from sites with poor and dry soils to sites with more rich and moist soils. Additionally, heterotrophic respiration was higher in mixed stands in comparison with monocultures. The highest respiration was observed in stands dominated by pine, which produces the greatest amount of litter (Hansson et al. 2011). In our simulations, the respiration was driven by the amount of litter, whereas the changes in the quality of the litter resulting from different tree species proportions had minor influence on respiration. A stimulation of microorganisms by increased litter diversity as suggested by Hättenschwiler et al. (2005) and Hättenschwiler and Gasser (2005) is not directly accounted in the current version of our model.

The differences in the amount of available nitrogen between stands on poor, medium and rich soils were remarkable and correspond to known experimental results that productivity increases with available nitrogen (Bhatti et al. 2002; Thomas et al. 2013).

\section{The dynamics of forest carbon stocks}

Increases in the carbon stock in the soil depend on site fertility, species composition and different redistributions of carbon between the forest floor and mineral soil. Forest floor undergoes the most significant changes in relation to species composition. Maximal increases were observed for mixed stands with large proportions of pine. This could be explained by the different rates of decomposition of litter from deciduous and coniferous trees (Wunderlich et al. 2012) and by the lower nitrogen content in pine litter fractions in comparison with spruce. Both factors lead to an increase in the carbon stock of the forest floor, a pattern most dramatically expressed on rich forest sites. Mixing pine with birch hastens decomposition and further humification, which is expressed by an increasing amount of organic matter in the mineral soil. Changes in mineral soil produced smaller differences (because it is a 'buffer' component with lower rates of transformation) but showed the same trends.

The carbon stock of standing biomass reflects NPP and was strongly affected by site fertility. Tree species 
composition strongly affected the standing biomass in coniferous stands, where a small proportion of long-lived pines with shade-tolerant spruce predominating formed stand with high standing biomass due to their complementary niches. This result indicates that dense sprucedominated coniferous stands, with their high capacity to sequestrate carbon, are the most efficient stand types for mitigating climate change.

\section{What is needed for further studies?}

We have shown that the succession of competing tree species is dependent on the physical and chemical properties of the soil, i.e. on site type. Thus, the response of forest stands to climate change and increased input of nitrogen compounds with precipitation may also be strongly dependent on site properties (e.g. Komarov and Shanin 2012). This means that results from experimental studies conducted on a single site or on sites with a small range of fertility variation cannot be generalized across a wide range of site conditions. Furthermore, in optimizing the management of mixed forest stands, site fertility level should be taken into account. To fully answer such questions focused on stand's response to the changing environment, a more detailed ecosystem model is required. The new components of such a model would be: (1) a submodel of regeneration, which is able to take into account the survival ability of saplings of different tree species depending on environmental conditions; (2) a sub-model simulating the composition of the ground layer and turnover of nutrients in herbs, grasses and shrubs; (3) a submodel of belowground competition, which takes into account the effect of soil properties (soil moisture, texture, etc.) on root spreading and uptake rate, and the differences in these properties in dependence of site type, as well as their alterations in time; and (4) a sub-model of productivity that is able to take into account the effects of droughts and the influence of soil water $\mathrm{pH}$. Also, it should be noted that we simulated only the dynamics of carbon, while forests are usually managed for multiple purposes (timber and non-timber products, biodiversity, recreation, etc.). Therefore, more complex system of models is required to estimate all ecosystem functions.

\footnotetext{
Acknowledgments This study was supported by the Academy of Finland (Project Numbers 140766 and 257845), by the Programme 4 of the Presidium of the Russian Academy of Sciences, by a collaborative project of the Russian Academy of Sciences and the Academy of Finland 'Adaptation of boreal forest management in the changing climate: modelling forest stand and soil development for main boreal tree species', and by the Russian Foundation for Basic Research, Grants Numbers 12-04-01269, 12-04-31635. We thank Dr. Sergey Bykhovets for preparation of the data on climate. We also would like to thank two anonymous reviewers for the constructive comments, which helped us to greatly improve the quality of the paper.
}

\section{References}

Bauwe A, Criegee C, Glatzel S, Lennartz B (2012) Model-based analysis of the spatial variability and long-term trends of soil drought at Scots pine stands in northeastern Germany. Eur J Forest Res 131:1013-1024

Bella IE (1971) A new competition model for individual trees. Forest Sci 17:364-372

Bhatti JS, Apps MJ, Jiang H (2002) Influence of nutrients, disturbances and site conditions on carbon stocks along a boreal forest transect in central Canada. Plant Soil 242:1-14

Bobbink R, Hicks K, Galloway J, Spranger T, Alkemade R, Ashmore M, Bustamante M, Cinderby S, Davidson E, Dentener F, Emmett B, Erisman J-W, Fenn M, Gilliam F, Nordin A, Pardo L, De Vries W (2010) Global assessment of nitrogen deposition effects on terrestrial plant diversity: a synthesis. Ecol Appl 20(1):30-59

Bugmann H (2001) A review of forest gap models. Clim Chang 51:259-305

Butterbach-Bahl K, Gundersen P, Ambus P, Augustin J, Beier C, Boeckx P, Dannermann M, Gimenso BS, Kiese R, Kitzler B, Ibrom A, Rees RM, Smith KA, Stevens C, Vesala T, ZechmeisterBoltenstern S (2011) Nitrogen processes in terrestrial ecosystems. In: Sutton MA, Howard CM, Erisman JW, Billen G, Bleeker A, Grennfelt P, van Grinsven H, Grizzetti B (eds) The European nitrogen assessment: sources, effects, and policy perspectives. Cambridge University Press, Cambridge, pp 99-125

Bykhovets SS, Komarov AS (2002) A simple statistical model of soil climate with a monthly step. Euras Soil Sci 35(4):392-400

Cajander AK (1926) The theory of forest types. Acta For Fenn 29(3): $1-108$

Cajander AK (1949) Forest types and their significance. Acta For Fenn 56:1-71

Cardinale BJ, Wright JP, Cadotte MW, Carroll IT, Hector A, Srivastava DS, Loreau M, Weis JJ (2007) Impacts of plant diversity on biomass production increase through time because of species complementarity. Proc Natl Acad Sci USA 104(46): 18123-18128

Cavard X, Bergeron Y, Chen HYH, Paré D, Laganiére J, Brassard B (2011) Competition and facilitation between tree species change with stand development. Oikos 120:1683-1695

Chertov OG, Komarov AS (1997) SOMM-a model of soil organic matter dynamics. Ecol Model 94:177-189

Chertov OG, Komarov AS, Nadporozhskaya MA, Bykhovets SS, Zudin SL (2001) ROMUL - a model of forest soil organic matter dynamics as a substantial tool for forest ecosystem modelling. Ecol Model 138(1-3):289-308

Coates KD, Canham CD, LePage PT (2009) Above- versus belowground competitive effects and responses of a guild of temperate tree species. J Ecol 97:118-130

Davidson EA, Janssens IA (2006) Temperature sensitivity of soil carbon decomposition and feedbacks to climate change. Nature 440:165-173

Forrester DI, Kohnle U, Albrecht AT, Bauhus J (2013) Complementarity in mixed-species stands of Abies alba and Picea abies varies with climate, site quality and stand density. For Ecol Manag 304:233-242

Gamfeldt L, Snäll T, Bagchi R, Jonsson M, Gustafsson L, Kjellander P, Ruiz-Jaen MC, Fröberg M, Stendah J, Philipson CD, Mikusiński G, Andersson E, Westerlund B, Andrén H, Moberg F, Moen J, Bengtsson J (2013) Higher levels of multiple ecosystem services are found in forests with more tree species. Nat Commun 4. doi:10.1038/ncomms2328

Gatzuk LE, Smirnova OV, Vorontsova LI, Zaugolnova LB, Zhukova LA (1980) Age state of plants of various growth forms: a review. J Ecol 68:675-696 
Grabarnik P, Särkka A (2009) Modelling the spatial structure of forest stands by multivariate point processes with hierarchical interactions. Ecol Model 220:1232-1240

Hansson K, Olsson BA, Olsson M, Johansson U, Kleja DB (2011) Differences in soil properties in adjacent stands of Scots pine, Norway spruce and silver birch in SW Sweden. For Ecol Manag 262:522-530

Hartmann H (2011) Will a 385 million year-struggle for light become a struggle for water and for carbon? How trees may cope with more frequent climate change-type drought events. Glob Chang Biol 17(1):642-655

Hättenschwiler S, Gasser P (2005) Soil animals alter plant litter diversity effects on decomposition. P Natl Acad Sci USA 102(5):1519-1524

Hättenschwiler S, Tiunov AV, Scheu S (2005) Biodiversity and litter decomposition in terrestrial ecosystems. Annu Rev Ecol Evol Syst 36:191-218

Hector A (1998) The effect of diversity on productivity: detecting the role of species complementarity. Oikos 82(3):597-599

Hobbie SE, Eddy W, Buyarski ChR, Adair EC, Ogdahl ML, Weisenhorn P (2012) Response of decomposing litter and its microbial community to multiple forms of nitrogen enrichment. Ecol Monogr 82(3):389-405

Holmgren M, Scheffer M (2010) Strong facilitation in mild environments: the stress gradient hypothesis revisited. J Ecol 98:1269-1275

Hotanen J-P, Nousiainen H, Mäkipää R, Reinikainen A, Tonteri T (2008) Metsätyypit—opas kasvupaikkojen luokitteluun [Forest types - guide to the classification of habitats]. Metsäkustannus, Helsinki, 192 p (In Finnish)

Huang J, Tardif JC, Bergeron Y, Denneler B, Berninger F, Girardin MP (2010) Radial growth response of four dominant boreal tree species to climate along a latitudinal gradient in the eastern Canadian boreal forest. Glob Chang Biol 16(2):711-731

Hynynen J, Repola J, Mielikäinen K (2011) The effect of species mixture on the growth and yield of mid-rotation mixed stands of Scots pine and silver birch. For Ecol Manag 262:1174-1183

Ilvesniemi H, Pumpanen J, Duursma R, Hari P, Keronen P, Kolari P, Kulmala M, Mammarella I, Nikinmaa E, Rannik Ü, Pohja T, Siivola E, Vesala T (2010) Water balance of a boreal Scots pine forest. Boreal Environ Res 15(4):375-396

Ilvessalo Y, Ilvessalo M (1975) Suomen metsätyypit metsiköiden luontalsen kehitys-ja puuntuotto-kyvyn valossa [The forest types of Finland in the light of natural development and yield capacity of forest stands]. Acta Forestalia Fennica 144:1-101 (Finnish with English summary)

Jõgiste KA (2000) Basal area increment model for Norway spruce in mixed stands in Estonia. Scand J For Res 15(1):97-102

Kelty MJ (1992) Comparative productivity of monocultures and mixed species stands. In: Kelty MJ (ed) The ecology of mixed species forests. Kluwer Academic Publishers, Dordrecht, pp 125-141

Kelty MJ (2006) The role of species mixtures in plantation forestry. For Ecol Manag 233(2-3):195-204

Komarov AS, Shanin VN (2012) Comparative analysis of the influence of climate change and nitrogen deposition on carbon sequestration in forest ecosystems in European Russia: simulation modelling approach. Biogeosciences 9(11):4757-4770

Komarov AS, Chertov OG, Zudin SL, Nadporozhskaya MA, Mikhailov AV, Bykhovets SS, Zudina EV, Zoubkova EV (2003a) EFIMOD 2-the system of simulation models of forest growth and elements cycles in forest ecosystems. Ecol Model 170:373-392

Komarov AS, Palenova MM, Smirnova OV (2003b) The concept of discrete description of plant ontogenesis and cellular automata models of plant populations. Ecol Model 170:427-439
Komarov AS, Chertov OG, Nadporozhskaya MA, Mikhailov AV, Bykhovets SS, Zudin SL, Priputina IV, Larionova AA, Grabarnik PYa, Zubkova EV, Zudina EV, Shanin VN, Andrienko G, Andrienko N, Martynkin AV, Mohren GMJ, Abakumov EV, Lukjanov AM, Kubasova TS, Bhatti J, Shaw S, Apps M, Bobrovsky MV, Khanina LG, Smirnov VE, Glukhova EM (2007) Modelirovanie dinamiki organicheskogo veshchestva v lesnykh ekosistemakh [Modelling Organic Matter Dynamics in Forest Ecosystems]. Nauka Publishing, Moscow, 380 p (Russian with English summary)

Kuzyakov Y, Friedel JK, Stahr K (2000) Review of mechanisms and quantification of priming effects. Soil Biol Biochem 32:1485-1498

Laasasenaho J (1982) Taper curve and volume functions for pine, spruce and birch. Commun Inst For Fenn 108:1-74

Lagergren F, Lindroth A (2002) Transpiration response to soil moisture in pine and spruce trees in Sweden. Agr For Meteorol 112:67-85

Larocque GR, Bhatti JS, Gordon AM, Luckai N, Wattenbach M, Liu J, Peng C, Arp PA, Liu S, Zhang CF, Komarov A, Grabarnik P, Sun J, White $T$ (2008) Chapter eighteen uncertainty and sensitivity issues in process-based models of carbon and nitrogen cycles in terrestrial ecosystems. In: Jakeman AJ, Voinov AA, Rizzoli AE, Chen SH (eds) Developments in integrated environmental assessment: environmental modelling, software and decision support, vol 3, pp 307-327. doi:10.1016/S1574101X(08)00618-2

LeBauer DS, Treseder KK (2008) Nitrogen limitation of net primary productivity in terrestrial ecosystems is globally distributed. Ecology 89:371-379

Légaré S, Paré D, Bergeron Y (2004) The responses of black spruce growth to an increased proportion of aspen in mixed stands. Can J For Res 34:405-416

Leps J (2005) Diversity and ecosystem function. In: Van Der Maarel E (ed) Vegetation ecology. Blackwell Publishing, Oxford, pp 199-237

Lindén M, Agestam E (2003) Increment and yield in mixed and monoculture stands on Pinus sylvestris and Picea abies based on an experiment in southern Sweden. Scand J For Res 18(2):155-162

Liu J, Ashton PS (1995) Individual-based simulation models for forest succession and management. For Ecol Manag 73:157-175

Loreau M (1998) Separating sampling and other effects in biodiversity experiments. Oikos 82(3):600-602

Loreau M, Hector A (2001) Partitioning selection and complementarity in biodiversity experiments. Nature 412:72-76

Martínez-Vilalta J, López BC, Adell N, Badiella L, Ninyerola M (2008) Twentieth century increase of Scots pine radial growth in NE Spain shows strong climate interactions. Glob Chang Biol 14(2):2868-2881

Mielikäinen K (1980) Manty-koivusekametsikoiden rakenne ja kehitys [Structure and development of mixed pine and birch stands]. Commun Inst For Fenn 99(3):1-82 (Finnish with English summary)

Mielikäinen K (1985) Koivusekoituksen vaikutus kuusikon rakenteeseen ja kehitykseen [Effect of an admixture of birch on the structure and development of Norway spruce stands]. Commun Inst For Fenn 133:1-79 (Finnish with English summary)

Morén A-S, Lindroth A, Flower-Ellis J, Cienciala E, Mölder M (2000) Branch transpiration of pine and spruce scaled to tree and canopy using needle biomass distributions. Trees 14:384-397

Morin X, Fahse L, Scherer-Lorenzen M, Bugmann H (2011) Tree species richness promotes productivity in temperate forests through strong complementarity between species. Ecol Lett 14:1211-1219

Norris MD, Avis PG, Reich PB, Hobbie SE (2013) Positive feedbacks between decomposition and soil nitrogen availability along fertility gradients. Plant Soil 367:347-361 
Oliver CD, Larson BC (1996) Forest stand dynamics. Wiley, New York $544 \mathrm{p}$

Olsson BA, Hansson K, Persson T, Beuker E, Helmisaari H-S (2012) Heterotrophic respiration and nitrogen mineralisation in soils of Norway spruce, Scots pine and silver birch stands in contrasting climates. For Ecol Manag 269:197-205

Paquette A, Messier C (2011) The effect of biodiversity on tree productivity: from temperate to boreal forests. Global Ecol Biogeogr 20:170-180

Piñeiro G, Perelman S, Guerschman JP, Paruelo JM (2008) How to evaluate models: observed vs. predicted or predicted vs. observed? Ecol Model 216:316-322

Porte A, Bartelink HH (2002) Modelling mixed forest growth: a review of models for forest management. Ecol Model 150:141-188

Pretzsch H (2010) Forest dynamics, growth and yield: from measurement to model. Springer, Berlin, p 664

Pretzsch H, Schütze G (2009) Transgressive overyielding in mixed compared with pure stands of Norway spruce and European beech in Central Europe: evidence on stand level and explanation on individual tree level. Eur J For Res 128:183-204

Pretzsch H, Grote R, Reineking B, Rötzer T, Seifert S (2008) Models for forest ecosystem management: a European perspective. Ann Bot 101:1065-1087

Pretzsch H, Block J, Dieler J, Dong PH, Kohnle U, Nagel J, Spellmann H, Zingg A (2010) Comparison between the productivity of pure and mixed stands of Norway spruce and European beech along an ecological gradient. Ann For Sci 67(712):1-12

Pretzsch H, Bielak K, Block J, Bruchwald A, Dieler J, Ehrhart H-P, Kohnle U, Nagel J, Spellmann H, Zasada M, Zingg A (2013) Productivity of mixed versus pure stands of oak (Quercus petraea (Matt.) Liebl. and Quercus robur L.) and European beech (Fagus sylvatica L.) along an ecological gradient. Eur J For Res 132(2):263-280

Pukkala T, Vettenranta J, Kolström T, Miina J (1994) Productivity of mixed stands of Pinus sylvestris and Picea abies. Scand J For Res 9:143-153

Rewald B, Leuschner C (2009) Belowground competition in a broadleaved temperate mixed forest: pattern analysis and experiments in a four-species stand. Eur J For Res 128:387-398

Shanin VN, Komarov AS, Mikhailov AV, Bykhovets SS (2011) Modelling carbon and nitrogen dynamics in forest ecosystems of Central Russia under different climate change scenarios and forest management regimes. Ecol Model 222:2262-2275

Shanin VN, Komarov AS, Khoraskina YuS, Bykhovets SS, Linkosalo T, Mäkipää R (2013) Carbon turnover in mixed stands: modelling possible shifts under climate change. Ecol Model 251:232-245

Shvidenko AZ, Schepaschenko DG, Nilsson S, Buluy YuI (2006) Tables and models of growth and productivity of forests of major forest forming species of Northern Eurasia (standard and reference materials). Ministry of Natural Resources of the Russian Federation, Federal Agency of Forest Management, Moscow

Smirnova OV, Bobrovskii MV (2001) Tree ontogeny and its reflection in the structure and dynamics of plant and soil covers. Russ J Ecol 32(3):159-163

Smirnova OV, Chistyakova AA, Zaugolnova LB, Evstigneev OI, Popadiouk RV, Romanovsky AM (1999) Ontogeny of a tree. Bot J St-Petersburg 84(12):8-20
Smolander A, Kitunen V (2011) Comparison of tree species effects on microbial $\mathrm{C}$ and $\mathrm{N}$ transformations and dissolved organic matter properties in the organic layer of boreal forests. Appl Soil Ecol 49:224-233

Sterba H, Blab A, Katzensteiner K (2002) Adapting as individual tree growth model for Norway spruce (Picea abies L. Karst.) in pure and mixed species stands. For Ecol Manag 159:101-110

Stoll P, Weiner J (2000) A neighbourhood view of interactions among individual plants. In: Dieckmann U, Law R, Metz JAJ (eds) The geometry of ecological interactions: simplifying spatial complexity. Cambridge University Press, Cambridge, pp 11-27

Talbot JM, Allison SD, Treseder KK (2008) Decomposers in disguise: mycorrhizal fungi as regulators of soil $\mathrm{C}$ dynamics in ecosystems under global change. Funct Ecol 22:955-963

Tamm CO (1991) Nitrogen in terrestrial ecosystems. Springer, Berlin $115 \mathrm{p}$

Tamminen P (1991) Kangasmaan ravinnetunnusten ilmaiseminen ja viljavuuden alueellinen vaihtelu Etelä-Suomessa [Expression of soil nutrient status and regional variation in soil fertility of forested sites in southern Finland]. Folia Forestalia 777:1-40 (Finnish with English summary)

Thelin G, Rosengren U, Callesen I, Ingerslev M (2002) The nutrient status of Norway spruce in pure and in mixed-species stands. For Ecol Manag 160(1-3):115-125

Thomas RQ, Bonan GB, Goodale CL (2013) Insights into mechanisms governing forest carbon response to nitrogen deposition: a model - data comparison using observed responses to nitrogen addition. Biogeosciences 10:3869-3880

Thorpe HC, Astrup R, Trowbridge A, Coates KD (2010) Competition and tree crowns: a neighborhood analysis of three boreal tree species. For Ecol Manag 259:1586-1596

Tilman D, Reich PB, Knops J, Wedin D, Mielke T, Lehman C (2001) Diversity and productivity in a long-term grassland experiment. Science 294:843-845

Tuomi M, Vanhala P, Karhu K, Fritze H, Liski J (2008) Heterotrophic soil respiration-comparison of different models describing its temperature dependence. Ecol Model 211:182-190

Venäläinen A, Tuomenvirta H, Pirinen P, Drebs A (2005) A basic Finnish climate data set 1961-2000-description and illustrations. Finnish Meteorological Institute, reports no. 5, $27 \mathrm{p}$

Vitousek PM, Howarth RW (1991) Nitrogen limitation on land and in the sea: how can it occur? Biogeochemistry 13:87-115

Weiner J (1990) Asymmetric competition in plant populations. Trends Ecol Evol 5:360-364

Wunderlich S, Schulz C, Grimmeisen W, Borken W (2012) Carbon fluxes in coniferous and deciduous forest soils. Plant Soil 357:355-368

Zhao D, Borders B, Wilson M, Rathbun SL (2006) Modeling neighborhood effects on the growth and survival of individual trees in a natural temperate species-rich forest. Ecol Model 196:90-102

Zianis D, Muukkonen P, Mäkipää R, Mencuccini M (2005) Biomass and stem volume equations for tree species in Europe. Silva Fennica Monographs, vol 4, $63 \mathrm{p}$ 